\title{
KEMELIMPAHAN FITOPLANKTON SEBAGAI BIOINDIKATOR DAN STATUS TROFIK DI ALIRANSUNGAI SIAK PEKANBARU
}

\author{
Rahmat Ramadansur ${ }^{1}$, Marta Dinata $^{2)}$ \\ ${ }^{1), 2)}$ Program Studi Pendidikan Biologi, Universitas Lancang Kuning \\ Email $^{1)}$ : rahmatramadansur89@unilak.ac.id \\ Email ${ }^{2}:$ martadinata@unilak.ac.id
}

\begin{abstract}
ABSTRAK: Tujuan penelitian ini untuk mengetahui (1) struktur komunitas fitoplankton di Aliran Sungai Siak Pekanbaru; (2) pengaruh faktor fisiko-kimia perairan terhadap kemelimpahan fitoplankton; (3) status trofik Sungai Siak Pekanbaru. Ditemukan 99 spesies fitoplankton di Sungai Siak dengan kemelimpahan $51.714 \mathrm{ind} / \mathrm{l}$, dimana kemelimpahan berkurang dengan bertambahnya kedalaman. Struktur komuntas fitoplanktonterdiri dari 6 kelas, yaitu Chlorophyta pada kelas Chlorophyceae sebesar 53\%, Euglenophycea pada kelas Euglenophyceae sebesar 6\%, Rhodophyta pada kelas Florideophyceae, sebesar 6\% Chrysophyta diwakili oleh kelas Xantophyceae sebesar 4\%, Bacillariophyta pada kelas Bacillariophyceae sebesar $18 \%$, Coscinodiseophyceae sebesar $8 \%$, Struktur komunitas fitoplankton di Sungai Siak memiliki keanekaragaman yang tinggi, kemerataan cukup dan dominansi yang rendah.Faktor fisiko-kimia yang berpengaruh positif terhadap kemelimpahan fitoplankton yaitu, $\mathrm{pH}$, suhu, turbiditas, kandungan fosfat, kandungan nitrat dan kecerahan, sedangkan yang memiliki pengaruh negatif yaitu BOD, COD, dan DO.Status trofik di Sungai Siak berkisar antara eutrofik sampai hipereutrofik yang berpotensi terjadi bloom alga sangat tinggi pada musim panas.

Kata kunci: Kelimpahan fitoplankton, struktur komunitas fitoplankton, status trofik
\end{abstract}

ABSTRACT: The purpose of this study was to determine (1) the structure of the phytoplankton community in the Pekanbaru Siak River Stream; (2) the influence of water physico-chemical factors on the abundance of phytoplankton; (3) the trophic status of the Pekanbaru Siak River. There were 99 species of phytoplankton in the Siak River with an abundance of 51,714 ind / l, where abundance decreased with increasing depth. The structure of the phytoplankton community consists of 6 classes, namely Chlorophyta in the Chlorophyceae class by 53\%, Euglenophycea in the Euglenophyceae class by 6\%, Rhodophyta in the Florideophyceae class, by 6\% Chrysophyta represented by the Xantophyceae class by 4\%, Baccinophyceaeae by $18 \%$, by $8 \%$, the phytoplankton community structure in the Siak River has high diversity, sufficient evenness and low dominance. Physico-chemical factors that have a positive effect on phytoplankton abundance are $\mathrm{pH}$, temperature, turbidity, phosphate content, nitrate content and brightness, while those has negative effects, namely BOD, COD, and DO. The trophic status in the Siak River ranges from 
eutrophic to hypereutrophic which has the potential for algal bloom to occur very high in the summer.

\section{Keywords: abundance of phytoplankton, phytoplankton community structure,} trophic status

\section{PENDAHULUAN}

Peningkatan jumlah penduduk dan perkembangan suatu kota berakibat pula pada pola perubahan konsumsi masyarakat yang cukup tinggi dari tahun ke tahun, dengan luas lahan yang tetap akan mengakibatkan tekanan terhadap lingkungan semakin berat. Terkait hal itu aliran sungai Siak yang merupakan wilayah perairan antara hulu dan hilir nya menuju laut.

Seringkali kegiatan industri berlangsung di sekitar daerah aliran sungai karena pihak industri mudah mendapatkan sumber air, akses transportasi dan membuang limbah ke sungai. Hal ini juga terjadi di sekitar aliran Sungai Siak. Pada daerah aliran Sungai Siak berlangsung berbagai kegiatan yang dapat menimbulkan polutan seperti kegiatan industri ( penambangan minyak bumi, pulp and paper, kelapa sawit, crumb rubber, plywood ), perkebunan, rumah tangga dan pelabuhan. Polutan dari berbagai kegiatan tersebut menyebabkan menurunnya kualitas air Sungai Siak. Hal ini tentunya akan memberikan pengaruh terhadap kulaitas air yang berwana coklah kehitaman. Menurut Ayi Bahtiar (2007) dan Subandi (2014) polutan dalam air mencakup unsur unsur kimia, pathogen/bakteri dan perubahan sifat Fisika dan kimia dari air. Banyak unsur unsur kimia merupakan racun yang mencemari air.

Masalah yang ditemui berdasarkan hasil studi pendahuluan dan observasi, dan wawancara pada masyarakat di aliran Sungai Siak pada tanggal 11 Januari 2021 pada nelayan yang berada di sekitar aliran sungai Siak, diperoleh hasil yaitu (1) Sunagai Siak mengalami peningkatan kesuburan perairan akibat aktivitas budidaya ikan air tawar yang cukup padat. Akitivitas budidaya ini menggunakan sistem keramba jaring apung.(2) Selain itu, diperoleh fakta bahwa pemberian pakan ikan yang rutin dilakukan nelayan mengakibatkan kekeruhan di setiap keramba ikan,.

Kemelimpahan fitoplankton adalah jumlah fitoplankton berbeda dari setiap stasiun yang diduga karena adanya beberapa faktor lingkungan yang mempengaruhi antara lain kecerahan, arus, dan unsur hara pada setiap stasiun dalam hal ini kandungan nitrat dan fosfat yang ada pada perairan (Samsidar et al., 2013). Berdasarkan hasil penelitian Samsidar et al. (2013) pada stasiun I kelimpahan fitoplankton berkisar 17278 ind/l, stasiun II berkisar 20959 ind/l, dan stasiun III berkisar 16847 ind/l, kemelimpahan tertinggi pada stasiun II disebabkan oleh oleh kandungan unsur hara dalam hal ini nitrat dan fosfat dan parameter lainnya cukup tinggi dan cocok untuk kehidupan 
fitoplankton dibandingkan dengan stasiun yang lain yaitu nitrat $0,0227 \mathrm{mg} / \mathrm{l}$ dan fosfat berkisar $0,0455 \mathrm{mg} / \mathrm{l}$. Menurut Juantari et al. (2008) kadar nitrat dan fosfat yang optimal untuk pertumbuhan fitoplankton sebagai berikut: $3,9 \mathrm{mg} / \mathrm{l}-15,5 \mathrm{mg} / \mathrm{l}$ dan 0,27 $\mathrm{mg} / \mathrm{l}-5,51 \mathrm{mg} / \mathrm{l}$. Nitrat dan fosfat merupakan faktor pembatas di bawah 0,144 mg/l dan 0,02 mg/l.

Fungsi fitoplankton dalam suatu perairan yaitu ekologinya sebagai produser primerdan awal mata rantai dalam jaring makanan menyebabkan fitoplankton sering dijadikan skala ukuran kesuburan suatu perairan. Tingkat berikutnya pemindahan energi dari produser ke tingkat trofik yang lebih tinggi melalui rantai makanan (Handayani \& Patria, 2005). Salah satu biota alga yaitu fitoplankton merupakan organisme yang mempunyai peranan besar dalam ekosistem perairan dan menjadi produser primer (Lacerda et al., 2004). Fitoplankton berfungsi dalam keseimbangan ekosistem perairan budidaya, juga berfungsi sebagai pakan alami di dalam usaha budidaya (Pirza \& Andi, 2008).

Fitoplankton terdiri dari berbagai spesies ganggang, yaitu Cyanophya (gangang hijau biru), Cryptophyceae (kriptofita), Dinaphycea (dinaflagelata), Chlorohyta(ganggang hijau), Euglenophyta (kelompok euglena), Bacillariophycea (diatom), Chrysophyceae (ganggang kuning keemasan). Beberapa diantaranya mempunyai flagella yang digunakan untuk bergerak, adapun yang tidak berflagel dapat meningkat jumlah sel atau bentuk koloni yang dapat mengurangi tingkat tenggelamnya (Suwono, 2011).

Bioindikator merupakan makhuk yang diamati penampakannya untuk dipakai sebagai petunjuk tentang keadaan kondisi lingkungan dan sumber daya pada habitatnya. Selain itu, Macgeoch (1998) dalam Setiawan (2008) menyatakan bioindikator adalah spesies atau kelompok spesies yang secara cepat dapat menggambarkan dampak perubahan lingkungan dari sebuah habitat, komunitas, atau ekosistem. Bioindikator adalah makhluk yang bisa digunakan sebagai penanda kualitas air dan menentukan kondisi dilingkungan dan sumber daya pada habitatnya. Selain itu, keberadaan fitoplankton dapat dijadikan sebagai bioindikator adanya perubahan lingkungan perairan yang disebabkan ketidak seimbangan suatu ekosistem akibat pencemaran (Ekwu \& Sikoki, 2006).

Wardhana (2004) menyatakan apabila air telah tercemar maka kehidupan manusia akan tergangu. Ini merupakan suatu bencana besar. Hampir semua makluk hidup di muka bumi ini memerlukan air, dari mikroorganisme sampai dengan mamalia tanpa air tiada keidupan di muka bumi.Sumber pencemaran perairan berdasarkan karakteristik limbah yang dihasilkan dapat dibedakan menjadi sumber limbah domestik dan sumber limbah non domestik. Sumber limbah domestik umumnya berasal dari daerah pemukiman penduduk dan sumber limbah non domestik berasal dari kegiatan seperti industri, pertanian dan peternakan, perikanan, pertambangan 
atau kegiatan yang bukan berasal dari wilayah pemukiman.

Suwono (2011) menyatakan struktur trofik adalah interaksi antara organisme di ekosistem melalui rantai makanan dan jaring makanan. Struktur trofik dapat diukur dan dinyatakan dalam jumlah energi yang disimpan atau energi yang ditambah per satuan luas persatuan waktu pada tingkatan trofik tertentu, dapat pula diukur dengan biomasa per satuan luas. Status trofik menurut Juantari et al (2013) ditentukan dari tiga parameter yaitu total $\mathrm{P}$, kecerahan air, dan klorofil-a. Carlson (1975) dalam Suwono (2011) mengembangkan metode untuk mengetahui status trofik suatu danau yang disebut sebagai Trophic State Index (TSI).

Status trofik sangat dipengaruhi oleh kepadatan fitoplankton (Goldman \& Horn,1983). Peningkatan unsur hara pada suatu perairan yang menggenang seperti waduk akan meningkatkan populasi berbagai spesies fitoplankton (Barus, 2002). Bellinger \& Singee
(2010) menyatakan bahwa fitoplankton pada lapisan permukaan (epilimnion) bisa digunakan sebagai salah satu penanda untuk mendeteksi status trofik Sungai berdasarkan produktif dan komposisi spesiesnya. Komposisi spesies dapat dihubungkan dengan status trofik melalui empat cara yaitu suksesi musiman, keanekaragaman, bioindikator, dan determinasi bioindeks. Jadi dapat disimpulkan status trofik adalah indikator yang bisa dijadikan tingkat kesuburan suatu perairan yang dapat diukur dari unsur hara yang terkandung di dalamnya dan tingkat kecerahan serta aktivitas biologi lainnya yang terjadi di suatu perairan.Selain itu, Carlson (1975) menyatakan bahwa determinasi status trofik dibuat berdasarkan evaluasi beberapa kriteria pembeda seperti bentuk kurva oksigen, komposisi spesies fitoplankton, konsentrasi nutrien dan macam pengukuran biomasa atau produksi.

Beberapa kriteria kualitas air yang menggambarkan status trofik suatu perairan tersaji dalam Tabel 1 berikut.

Tabel 1 Kriteria Kualitas Air Berdasarkan Status Trofik

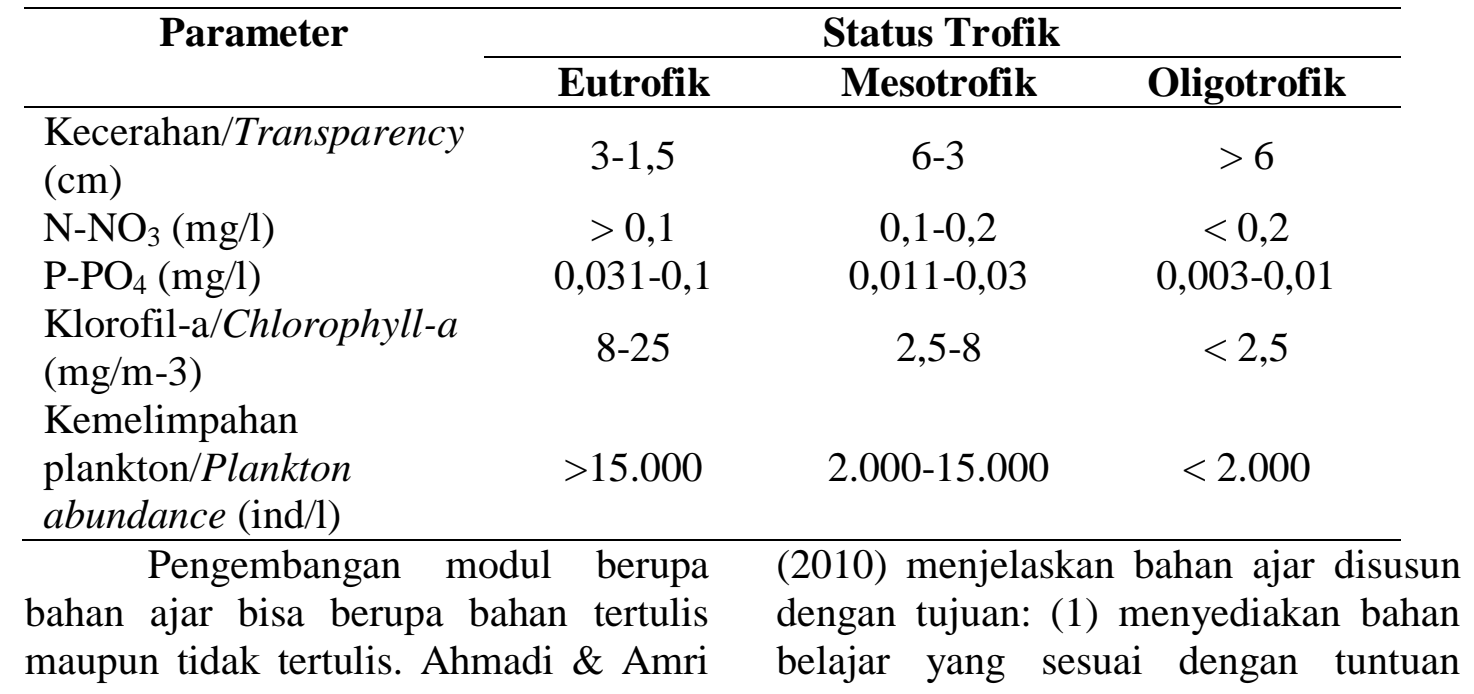


kurikulum dengan mempertimbangan kebutuhan peserta didik, (2) membantu peserta didik dalam memperoleh alternatif bahan ajar, dan (3) memudahkan guru dalam melaksanakan pembelajaran.

Trianto (2010) menyatakan bahwa bahan ajar merupakan bagian dari sumber belajar yang dapat digunakan untuk membantu guru/instruktur dalam melaksanakan kegiatan belajar mengajar. Sumber belajar akan menjadi bermakna bagi peserta didik maupun guru, apabila sumber belajar diorganisasi melalui satu rancangan yang memungkinkan seseorang dapat memanfaatkannya sebagai sumber belajar. Jika tidak maka tempat atau lingkungan alam sekitar, benda, orang, dan atau buku hanya sekedar tempat, benda, orang atau buku yang tidak ada artinya apapun (Depdiknas, 2008).

Pengembangan modul belajar siswa mencakup pengetahuan, keterampilan dan sikap yang dipersyaratkan untuk menguasai suatu kompetensi. Melalui modul, mahasiswa diharapkan mampu memiliki retensi yang kritis dan keterampilan seperti kemampuan melakukan kolaborasi, komunikasi, pembuatan keputusan, dan jiwa kepemimpinan yang tidak mudah didapatkan di kelas Rea et al. (2007).

Sedangkan menurut Nasution (2008) modul adalah suatu unit yang lengkap, yang berdiri sendiri dan terdiri atas suatu rangkaian kegiatan belajar yang disusun untuk membantu siswa mencapai sejumlah tujuan yang dirumuskan secara khusus dan jelas. Nasution (2008) menyatakan tujuan modul yaitu: (a) membuka kesempatan bagi siswa untuk belajar menurut pemahaman mereka sendiri. Dianggap siswa tidak akan mencapai hasil yang sama dalam waktu yang sama dan tidak bersedia mempelajari sesuatu pada waktu yang sama, (b) memberikan kesempatan bagi siswa untuk belajar menurut cara masing-masing, oleh sebab mereka menggunakan teknik yang berbeda untuk memecahkan masalah tertentu berdasarkan latar belakang pengetahuan dan kebiasaan masing, (c) memberikan pilihan dari sejumlah besar topik dalam rangka suatu mata pelajaran, mata kuliah, bidang studi atau disiplin bila kita anggap bahwa pelajar tidak mempunyai pola minat yang sama atau motivasi yang sama untuk mencapai tujuan yang sama, dan (d) memberi kesempatan pada siswa untuk mengenal kelebihan dan kekurangannya dan memperbaiki kelemahannya melalui modul remedial, ulangan atau variasi dalam belajar. Berdasarkan latar belakang di atas maka penelitian ini bertujuan penelitian untuk mengetahui (1) struktur komunitas fitoplankton di Waduk Lahor, Malang; (2) pengaruh faktor fisiko-kimia perairan terhadap kemelimpahan fitoplankton; (3) status trofik Waduk Lahor dan (4) mengembangkan hasil penelitian kemelimpahan fitoplankton sebagai bioindikator dan status trofik perairan sebagai modul perkuliahan limnologi

\section{METODE PENELITIAN}

Model penelitian ini mengunakan pendekatan kualitatif dengan metode deskriptif. Peneliti berusaha untuk mengungkapkan fakta sesuai dengan kenyataan yanga da tanpa melakukan intervensi terhadap kondisi 
yang terjadi. Penelitian kualitatis berujuan untuk membuat gambaran dan hubungan antara fenomena yang disediki. Penelitian desriptif tidak memeberikan perlakuan, manipulasi, atau pengubahan pada variabel-variabel bebas, tetapi mengambarkan suatu kondisi apa adanya.

Penelitian ini dilaksanakan pada bulan Oktober 2020, dimana lokasi pengambilan data bertempat di perairan sungai Siak. Provinsi Riau Kota Pekanbaru Tahapan pegambilan sampel yaitu (1) pencuplikan sampel fitoplankton dan sampel air dilaksanakan secara in-situ, (2) pengukuran faktor fisika-kimia yang meliputi suhu, salinitas kecerahan, kekeruhan, $\mathrm{pH}$, oksigen terlarut (DO) dilaksanakan secara in-situ dan faktor kimia yang meliputi BOD, COD, kadar nitrat, kadar fosfat, dilaksanakan secara ex-situ, (3) pengukuran nilai indek keanekaragaman,

dominansi, dan

(4) pengambilan gambar dan pencacahan fitoplankton.

Rumus untuk menghitung kemelimpahan, kemelimpahan relatif, hubungan faktor fisiko-kimia terhadap kemelimpahan, keanekaragaman, kemerataan, dominansi, statu trofik, menghitung validasi, dan uji keterbacaan sebagai berikut.
1. Mengidentifikasi fitoplankton dari setiap stasiun kemudian di masukkan ke tabel tabulasi data taksa fitoplankton.

2. Menentukan kemelimpahan dan kemelimpahan relatif fitoplankton menggunakan perhitungan kemelimpahan fitoplankton dengan rumus (Fachrul, 2007) sebagai berikut:

$$
\mathrm{N}=\mathrm{n} \times\left(\frac{V r}{V o}\right) x\left(\frac{1}{V s}\right)
$$

Keterangan:

$\mathrm{N}=$ Jumlah (sel/1)

$\mathrm{n}=$ Jumlah sel yang terindentifikasi

$\mathrm{Vr}=$ Volum air yang terendap $(50 \mathrm{ml})$

$\mathrm{Vo}=$ Volum air yang diamati pada

Counting Chamber (1ml)

Vs = Volum air yang di ambil (1,5 L)

$$
\mathrm{KR}=\frac{\text { kemelimpahan sp.a }}{\sum \text { kemelimpahan }} \times 100 \%
$$

Keterangan:

$\mathrm{KR}=$ Kemelimpahan Relatif

3. Menetukan hubungan antara faktor fisiko-kimia terhadap kemelimpahan fitoplanton dengan rumus sebagai berikut.

Tabulasi data yang digunakan untuk menganalisis data dengan analisis berganda tertera pada Tabel 2

\begin{tabular}{|c|c|c|}
\hline $\begin{array}{c}\text { Stasiun, } \\
\text { Kedalaman }\end{array}$ & $\begin{array}{c}\text { Faktor Fisiko-Kimia } \\
X_{1} X_{2} X_{3} X_{. .} X_{9}\end{array}$ & Kemelimpahan \\
\hline $\mathrm{S} 1, \mathrm{~K} 1$ & & \\
\hline $\mathrm{S} 2, \mathrm{~K} 2$ & & \\
\hline S3, K3 & & \\
\hline
\end{tabular}

\section{Tabel 2Tabulasi Data untuk Analisis Regresi}


4. Menentukan nilai indeks keanekaragaman dilakukan perhitungan dengan rumus indeks Shannon-Wienner(Sumber: Odum, 1993:184).

$$
H^{\prime}=-\sum_{t=1}^{s} p i \operatorname{In} p i
$$

Keterangan:

$\mathrm{H}^{\prime} \quad=$ Indeks

keanekaragaman

Shannon-Wienner

$\mathrm{Pi} \quad=n \mathrm{i} / \mathrm{N}$

$\mathrm{ni} \quad=$ jumlah

individu jenis $\mathrm{ke}-\mathrm{i}$

$\mathrm{N} \quad=$ jumlah total individu

$\mathrm{S} \quad=$ jumlah genus

Hasil yang telah diperoleh kemudian dimasukkan kedalam kolom tabel yang sesuai, nilai indeks keanekaragaman disesuaikan pada kriteria dalam Tabel 3.

Tabel 3 Kriteria Tingkat Pencemaran

\begin{tabular}{ll}
\hline \multicolumn{1}{c}{ Nilai H' } & \multicolumn{1}{c}{ Kriteria } \\
\hline $\mathrm{H}^{\prime}>2.0$ & Tidak tercemar \\
$1.6<\mathrm{H}^{\prime}<2.0$ & Tercemar ringan \\
$1.0<\mathrm{H}^{\prime}<2.0$ & Tercemar sedang \\
$\mathrm{H}^{\prime}<1.0$ & Tercemar berat \\
\hline
\end{tabular}

(Sumber: Kreb, 1985: 250)

5. Menentukan nilai tingkat kemerataan fitoplankton digunkan rumus indeks kemerataan dengan menggunakana rumus (Kwak \& Peterson, 2007) sebagai berikut:

Keterangan:

$$
\mathrm{J}=\frac{H}{L n S}
$$

$\mathrm{J}=$ indeks kemerataan
$\mathrm{H}=$ indeks keanekaragaman

$\mathrm{S}=$ jumlah takson jenis

6. Menentukan nilai indeks dominansi fitoplankton digunakan rumus menggunakan rumus (Fachrul, 2007) sebagai berikut:

$$
D=\sum_{i=1}^{s}\left(\frac{n i}{N}\right) 2
$$

Keterangan:

$\mathrm{D}=$ Indeks dominansi

$\mathrm{ni}=$ Nilai penting untuk tiap spesies (jumlah individu)

$\mathrm{N}=$ Total nilai penting

Hasil yang diperoleh kemudian disesuaikan pada kolom nilai kisaran dan kategori dominansi yang tersedia pada Tabel 5 .

\begin{tabular}{|c|c|}
\hline Nilai D & Dominansi \\
\hline $\begin{array}{l}\mathrm{D}<0,4 \\
0,4<\mathrm{D} \leq 0,6 \\
\mathrm{D}>0,6\end{array}$ & $\begin{array}{l}\text { Dominansi populasi } \\
\text { rendah } \\
\text { Dominansi populasi } \\
\text { sedang } \\
\text { Dominansi populasi } \\
\text { tinggi }\end{array}$ \\
\hline \multicolumn{2}{|c|}{$\begin{array}{l}\text { (Sumber:Fachrul, 2007) } \\
\text { 7. Penentuan status trofik Sungai Siak } \\
\text { menggunakan rumus } \\
\text { TSI(Carlson,1975) } \\
\text { sebagai berikut. }\end{array}$} \\
\hline TSI-P & $=\underset{(\mathrm{ug} / \mathrm{I})}{14.42 \mathrm{TP})}+4,15$ \\
\hline TSI-Cla & $\begin{array}{l}=30.6+9.81 \times \text { xN } \\
(\text { Chlor }-a) \quad(\mathrm{ug} / \mathrm{I})\end{array}$ \\
\hline TSI-SD & $=60-\underset{\text { (meter) }}{14.41 \times \operatorname{Ln}(\text { sechi })}$ \\
\hline
\end{tabular}

Tabel 5 Nilai Kisaran dan Kategori Dominansi 
Rerata TSI $=($ TSI-P + TSI-Cla + $\underline{\text { TSI-SD) }}$

3

Keterangan:

TSI-P = hasil perhitungan TSI untuk fosfat

TSI-Cla = hasil perhitungan TSI untuk klorofil-a

TSI-SD = hasil perhitungan TSI untuk kedalamn sechi

\section{HASIL DAN PEMBAHASAN}

\subsection{Kemelimpahan Fitoplankton}

Secara keseluruhan fitoplankton yang teridentifikasi di Sungai Siak Waduk Lahor terdapat 99 spesies, dan diklasifikasikan 5 divisi yaitu Chlorophyta, Euglenophyta, Chrysophyta, Bacilariophyta, dan
Rhodophyta. Filum Chlorophyta diwakili oleh kelas Chlorophyceae. Filum Euglenophyta diwakili oleh kelas Euglenophyceae. Filum Chrysophyta diwakili oleh kelas Xantophyceae, Filum Bacillariophyta diwakili oleh kelas Bacilariophyceae, Coscinodiseophyceae, dan filum Rhodophyta diwakili oleh Florideophyceae

$\begin{array}{cr}\text { Kemelimpahan } & \text { relatif } \\ \text { berdasarkan kelas yaitu yaitu }\end{array}$ Chlorophyceae memiliki frekuensi relatif tertinggi yaitu sebesar $53 \%$, Kemudian frekuensi relatif Bacillariophyceae sebesar $18 \%$, Xantophyceae sebesar $4 \%$, Coscinodiseophycea sebesar $8 \%$, Euglenophyceae sebesar $11 \%$, kemudian Florideophyceae sebesar $6 \%$ terlihat pada Gambar 1.

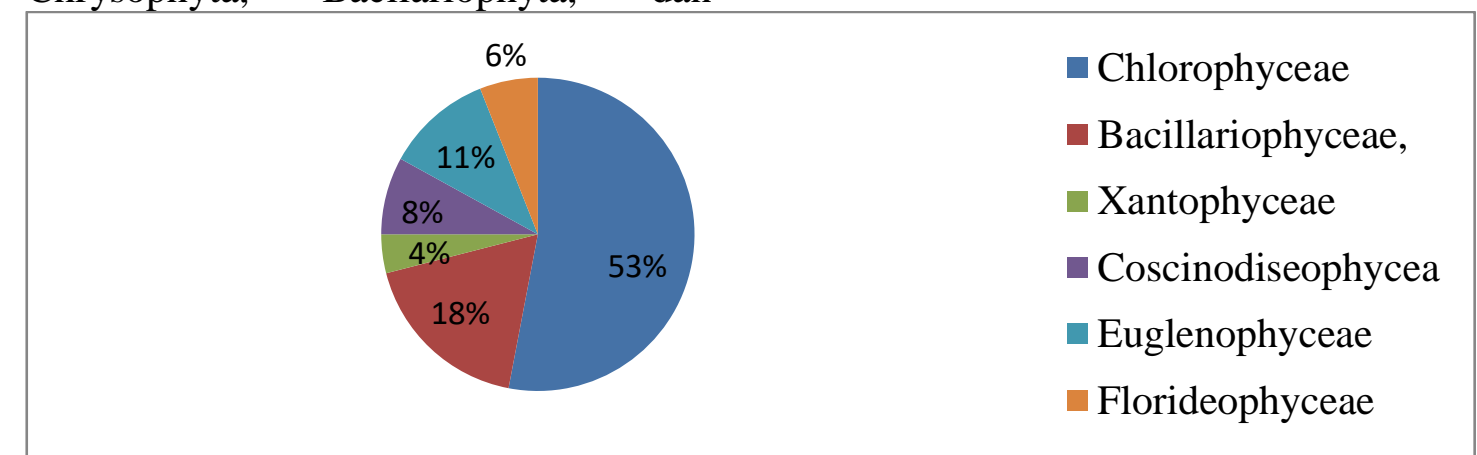

\section{Gambar 1. Frekuensi Relatif Fitoplankton di Perairan Waduk Lahor}

Pertumbuhan Euglenophyceae, Florideophyceae, Fragilariophyceae, Xantophyceae, Coscinodiseophyceae lebih optimum pada epilimnion karena penetrasi yang diperlukan untuk fotosintesis pada lapisan ini sangat optimum. Akan tetapi rendahnya frekuensi dari kelompok ini kemungkinan disebabkan oleh faktor fisiko-kimia lainnya seperti nutrient dan $\mathrm{pH}$ yang kurang, dan lain sebagainya yang menyebabkan pertumbuhan pada kelas ini terhambat. Sitoki (2010) dalam Ngodhe et al. (2013) menyebutkkan spesies yang berbeda dapat bertahan berdasarkan variasi kadar nutrient dan spesies lain yang bersaing mendapatkan nutrient yang sama. Setiawan (2008) menyatakan kemelimpahan fitoplankton yang relatif tidak sama atau berbeda. Berkaitan dengan suhu 
perairan dan faktor intensitas cahaya.

Kemelimpahan juga ditunjukkan berdasarkan rona lingkungan seperti tertera pada Tabel 7.

Tabel 7 Kemelimpahan

Fitoplankton Berdasarkan Rona Lingkungan

\begin{tabular}{clc}
\hline No & Stasiun & $\begin{array}{c}\text { Total } \\
\text { Kemelimpahan } \\
\text { (Ind/l) }\end{array}$ \\
\hline 1 & Stasiun 1 & 14.812 \\
2 & Stasiun 2 & 12.349 \\
3 & Stasiun 3 & 12.042 \\
4 & Stasiun 4 & 12.511 \\
\hline
\end{tabular}

\subsection{Struktur Komunitas}

Hasil nilai keanekaragaman, kemerataan, dominansi berdasarkan rona lingkungan di setiap stasiun diperoleh hasil sebagai berikut. Hasil menunjukkan pada stasiun diperoleh rerata nilai keanekaragaman sebesar 4,47 , rerata nilai kemerataan sebesar 0,96 dan rerata nilai dominasi 0,03 . Hasil tercantum dalam Gambar 2.

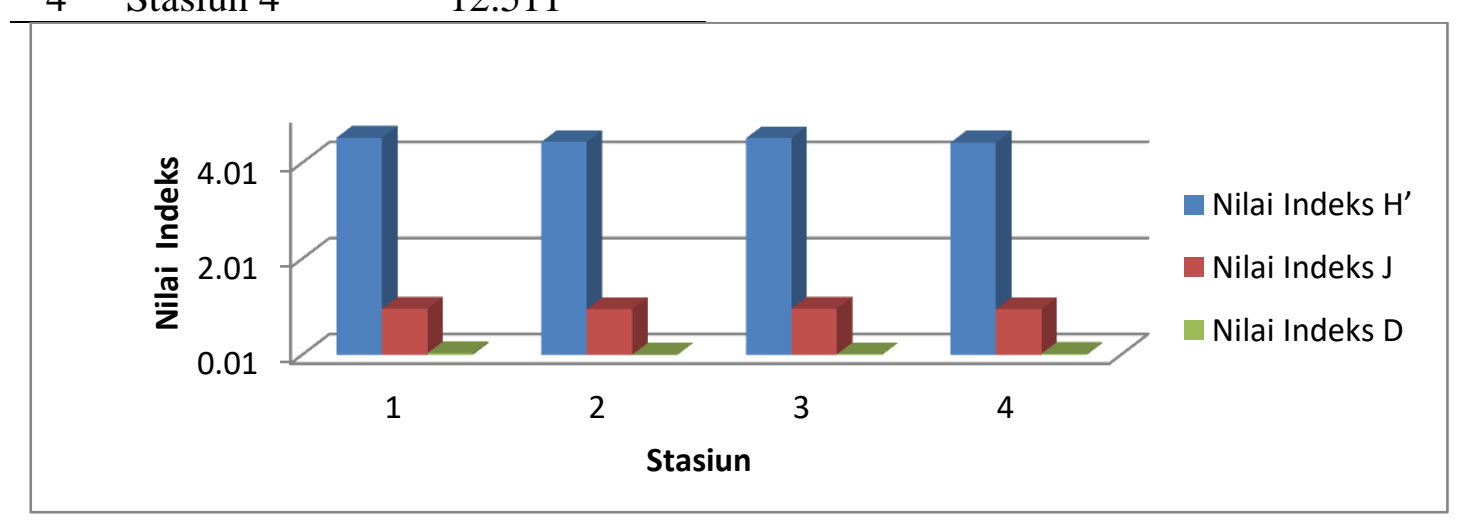

\section{Gambar 2 Perbandingan Nilai Indeks Keanekaragaman, Kemerataan, dan Dominansi Fitoplankton Pada Setiap Stasiun}

Berdasakan hasil analisis diketahui bahwa secara keseluruhan indeks keanekaragaman komunitas fitoplankton di perairan Sungai Siak Pekanbaru sebesar 4,47 , berdasarkan kategori penilaian indeks keanekaragaman oleh Wilhm (1975) dapat dinyatakan bahwa tingkat keanekargaman spesies fitoplankton di Waduk Lahor termasuk jumlah individu tiap spesies tinggi, dan kestabilan ekosistem tinggi. Selain itu, berdasarkan kriteria tingkat pencemaran oleh Krebs (1985) maka, dinyatakan bahwa perairan sungai Siak termasuk dalam kategori tidak tercemar. Untuk nilai kemerataan sebesar 0.96. Nilai indeks ini cukup besar, sehingga jika dimasukkan skala Pielou 0-1 untuk mengetahui tingkat persentase (nilai indeks masuk rentang 0,76-0,96), maka dapat dinyatakan bahwa penyebaran spesies fitoplankton di perairan sungai Siak hampir 
merata. Indeks dominansi fitoplankton di perairan sungai Siak Pekanbaru sebesar 0.03. Nilai indeks ini terlihat mendekati 0 sehingga dapat dinyatakan bahwa tidak ada spesies yang mendominansi dalam komunitas fitoplankton di perairan sungai Siak Pekanbaru. Berdasarkan kriteria penilaian dominasi Krebs (1985), indeks dominansi cukup rendah (D < 0.4) sehingga dapat dinyatakan bahwa dominansi spesies rendah.

\subsection{Faktor Fisiko-Kimia}

Hasil pengukuran fisiko-kimia perairan yang terdiri dari $\mathrm{BOD}, \mathrm{COD}$, kadar fosfat, kadar nitrat, $\mathrm{pH}, \mathrm{DO}$, suhu, kecerahan dan turbiditas. Pengukuran faktor fisiko pada Perairan di setiap stasiun terlihat suhu tertinggi pada stasiun 4 yaitu $29,77{ }^{\circ} \mathrm{C}$ dan terendah pada stasiun 1 yaitu $27,47{ }^{\circ} \mathrm{C}$ dengan rerata suhu perairan sebesar $28,12{ }^{\circ} \mathrm{C}$, tingginya suhu di suatu perairan disebabkan oleh kondisi pencahayaan dimana tingginya suhu ini berhubungan positif pada kemelimpahan Chlorophyceae. sedangkan turbidatas terendah terdapat pada stasiun 1, dan 2 yaitu $0,65 \mathrm{mg} / \mathrm{l}$ dan $1,21 \mathrm{mg} / \mathrm{l}$. Rerata turbiditas perairan Siak sebesar 1,31 $\mathrm{mg} / \mathrm{l}$. Kecerahan tertinggi terdapat pada stasiun 3 yaitu $85,00 \mathrm{~cm}$, sedangkan kecerahan terendah terdapat pada stasiun 2 yaitu sebesar $69,13 \mathrm{~cm}$. Secara keseluruhan, rerata kecerahan perairan sungai Siak Pekanbaru sebesar 79,41 cm. Pengukuran analisis faktor kimia pada Sungai Siak, BOD pada ke empat stasiun bekisar antara 3,05-4,22 mg/l. Nilai BOD tertinggi terlihat pada stasiun 2 , sedangkan nilai
BOD yang terendah terdapat pada stasiun 3. Nilai COD berkisar antara 6,17-9,43 mg/l, selain itu, COD tertinggi terdapat pada stasiun 1, dan COD yang terendah terdapat pada stasiun 3. Kadar fosfat berkisar antara 0,05-0,11 $\mathrm{mg} / \mathrm{l}$, pada kadar fosfat setiap stasiun 1 dan 3 memiliki nilai yang sama sebesar $0,05 \mathrm{mg} / \mathrm{l}$, untuk nilai fosfat terendah terdapat pada stasiun 2 sebesar $0,05 \mathrm{mg} / \mathrm{l}$. Kadar nitrat berkisar $0,25-0,53 \mathrm{mg} / \mathrm{l}$, tingginya nilai ketersediaan nutrien baik fosfat dan nitrat biasanya berkorelasi positif pada tingkat kedalaman (Amarnath et al., 2013). Sedangkan kadar nitrat tertinggi terdapat pada stasiun 1 sedangkan kadar nitrat terendah terdapat pada stasiun 3. Nilai $\mathrm{pH}$ menunjukkan derajat keasaman perairan nilai $\mathrm{pH}$ yang terukur berkisar antara 8,31-8.00 $\mathrm{mg} / \mathrm{l}$ atau dengan kata lain perairan sungai Siak Pekanabaru, tergolong basa lemah. $\mathrm{pH}$ terendah terdapat pada stasiun 1, dan $\mathrm{pH}$ tertinggi pada stasiun 3. Kadar DO yang terukur di perairan Sungai Siak Pekanbaru berkisar antara 7,40-3,15 mg/l, dimana kadar DO tertinggi terdapat pada stasiun 1 dan untuk kadar DO terendah terdapat pada stasiun 3 .

\subsection{Regresi Faktor Fisiko-Kimia terhadap Fitoplankton}

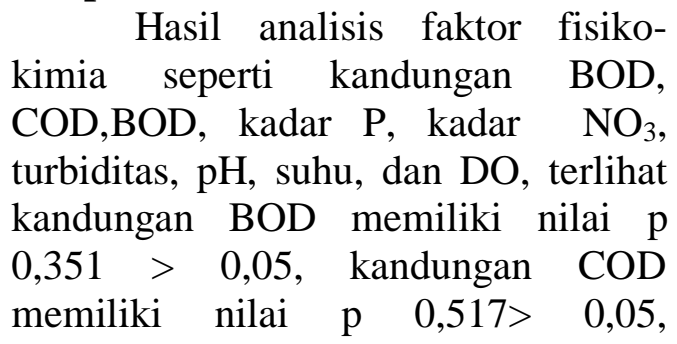


Kandungan DO memiliki nilai $p$ 0,364>0,05 dengan demikian dapat dikatakan BOD, COD dan DO yang memiliki nilai $\mathrm{p}$ lebih besar dari 0,05 tidak berpengaruh terhadap kemelimpahan fitoplankton. Kemudian $\mathrm{p}$ untuk $\mathrm{pH}$ sebesar 0,058, suhu sebesar 0,001 , turbiditas sebesar 0,10 , kandungan $\quad \mathrm{NO}_{3}$ sebesar $\quad 0,07$.
Kandungan fosfat sebesar 0,025, kecerahan sebesar 0,028. Hasil faktor fisiko-kimia yang memiliki nilai signifikan lebih kecil dari 0,05 maka dapat diartikan bahwa nilai tersebut berpengaruh signifikan terhadap kemelimpahan fitoplankton. Hasil tercantum pada Tabel 3.

Tabel 3 Ringkasan Coefficients Pengaruh Faktor Fisiko-kimia terhadap Kemelimpahan Fitoplankton

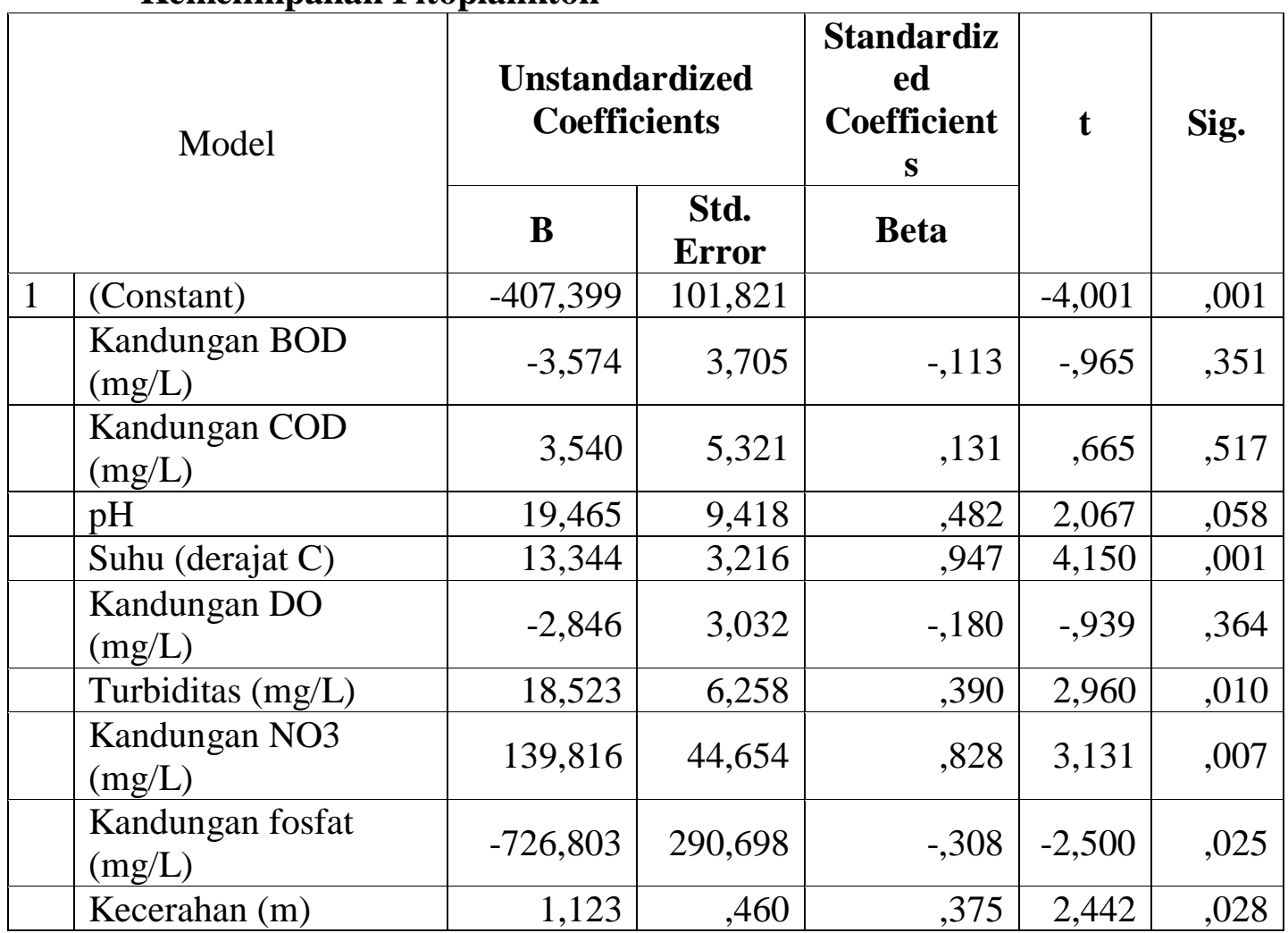

\subsection{Status Trofik}

Hasil status trofik Sungai Siak menggunakan 3 parameter yaitu klorofil-a sebesar $1480 \mathrm{ug} / \mathrm{l}$, total fosfat sebesar $170 \mathrm{ug} / \mathrm{l}$, dan kecerahan sebesar $0,81 \mathrm{~m}$. Status trofik Sungai Siak Pekanbaru ini menggunakan rumus indeks Carlson \& Lamarelli, menunjukkan bahwa rumus indeks status trofik Carlson fosfat sebesar 80,27, rerata TSI klorofil-a sebesar 102,21, dan rerata TSI kecerahan sebesar 65,46. Sehingga dapat diperoleh rerata TSI sebesar 83,11 
berdasarkan kriteria penentuan status trofik Carlson, rerata TSI > 82, sehingga dapat dikatakan bahwa Sungai Siak Pekanbaru berstatus hipereutrofik. Berdasarkan rumus indeks Lamparelli, rerata TSI fosfat sebesar 62.56, rerata TSI klorofil-a sebesar 86,77, dan rerata TSI kecerahan sebesar 70,12. Berdasarkan kriteria penentuan status trofik Lamparelli, rerata TSI berada pada rentang 59-63, dengan nilai rerata sebesar 80,21 sehingga dapat dinyatakan bahwa Sungai Siak Pekanbaru berstatus hipereutrofik.

Dari hasil kedua analisis dengan menggunakan kedua rumus indeks status trofik, maka diperoleh simpulan bahwa perairan Sungai Siak berada pada pada status hipereutrofik. Tingginya nilai fosfat pada indeks Carlson dan Lamparelli ini disebabkan sumber aliran nutrien berasal dari bawah tanah yang mengalirkan nutrien dari area persawahan di area perairan Sungai Siak memperkaya nutrien yang terdapat pada perairan. Aliran pertanian memiliki DO yang rendah dan konduktivitas yang tinggi, serta kaya akan nitrogen dan fosfat sehingga berperan penting dalam eutrofikasi (Rahmani et al., 2013). Disamping limbah rumah tangga diduga berperan besar dalam menyebabkan eutrofikasi. Sejalan dengan pendapat Sediadi (1999) bahwa pembudidayaan ikan, kegiatan rumah tangga seperti mencuci, bertani, dan lain sebagainya berdampak besar terhadap meningkatnya eutrofikasi perairan. Seperti penelitian Fadhlya (2010) yang mengatakan sumber pencemaran pada Waduk Saguling berasal dari limbah domestik yang berasal dari penduduk sekitar waduk, limbah pertanian, lahan surutan dan limbah perikanan.

\section{KESIMPULAN}

Berdasarkan hasil penelitian dapat diketahui kemelimpahan fitoplankton di waduk Lahor terdiri dari 99 spesies dan diklasifikasi menjadi 5 divisi yaitu Chlorophyta, Euglenophyta, Chrysophyta, Bacilariophyta, dan Rhodophyta. Kemelimpahan fitoplankton di Sungai Siak diketahui sebesar 51.714 ind/l, kemudian untuk struktur komunitas fitoplankton di Sungai Siak memiliki pada setiap stasiun memiliki rerata nilai keanekaragaman sebesar 4,47, nilai kemerataan sebesar 0,96, dan rerata nilai dominansi sebesar 0,03 .

Berdasarkan hubungannya antara faktor fisiko-kimia terhadap kemelimpahan yang memiliki hubungan positif yaitu kadar $\mathrm{NO}_{3}$, suhu, turbiditas, dan kecerahan, dan yang memiliki hubungan negatif terhadap kemelimpahan yaitu BOD, COD, pH dan Kandungan DO. Berdasarkan hasil analsis status trofik Sungai Siak Pekanbaru pada kriteria Carlson memiliki rerata nilai sebesar 83,11 dan berstatus hipereutrofik, sedangkan kriteria Lamparelli memiliki rerata nilai sebesar 80,21 dengan kriteria hiperutrofik ringan, untuk

\section{DAFTAR PUSTAKA}

Barus, T. A. 2002. Pengantar Limnologi. Jakarta: Direktorat Pembinaan Penelitian dan Pengabdian pada Masyarakat. 
Bellinger, E. G., \& Singee, D. C. 2012.Freshwater Algae: identification and Use as Bioindicator. UK: A John Wiley \& Sons, Ltd, Publication Carlson, R. E. 1975. A Trophic State Index for Lakes. Pacific Section American Society of Limnology and Oceanography, Inc.

(Online),(http://also.org/lo/toc/ vol_22/issue_2/0362.pdf), diakses pada 24 Januari 2015.

Ekwu, A.O., \& Sikoki F.D. 2006. Phytoplankton Diversity In The Cross River Estuary of Nigeria, Journal of Applied Sciences

\&EnvironmentalManagement , 10 (1): 89-95.

Fadhlya, N. 2010. Dinamika Eutrofikasi yang Disebabkan oleh Perubahan Nitrogen dan Fosfat: Studi Kasus Waduk Saguling, Jawa Barat. Tesis tidak diterbitkan. Jakarta: Pascasarjana Universitas Indonesia. (Online) (http://lontar.ui.ac.id), diakses tanggal 3 Juni 2015.

Fachrul, M. F. 2007. Metode Sampling Bioteknologi. Jakarta: Penerbit Bumi Aksara.

Ganaj, A.H., \& Parveen, S. 2014. Effect of Physico-chemical Condition on the Structure and Composition of the Phytoplankton Community in Wular Lake at Lankrishipora, Kashmir.Internasional Journal of Biodiversity and Conservation 6 (1): 71-84 (2014)
Goldman, C. R., \& Horne A. J., 1983. Limnology. America: McGrawHill Book Company.

Handayani, S \& Patria, M. P. 2005. Komunitas Zooplankton di Perairan Waduk Krenceng, Cilegon, Banten, Jurnal Makara, Sain, 9 (2):75-80.

Juantari, G. Y., Sayekti, R. W., \& Harisuseno, D. 2013. Status Trofik dan Daya Tampung Beban Pencemaran Waduk Sutami, Jurnal Teknik Pengairan 4 (1) : 61-66

Krebs, C. J. 1985. Experimental Analysis of Distribution and Abudance. Philadelphia: Harper \& Row Publisher.

Kwak, T. J, \& Peterson, J. T. 2007. Community Indices, Parameter, and Comparisons. (Online), (http://www4.ncsu.edu/ tkwak/ Kwak26_Peterson_2007.Pdf), diakses pada 27 Juli 2015.

Lacerda, S R., Koening M. L., Neumann-Leitão S., \&FloresMontes M.J. 2004. Phytoplankton Nyctemeral Variation at a Tropical River Estuary (ItamaracáPernambuco-Brazil). Brazilian Journal of Biology, 64 (1): 8194.

Nasution. 2008. Berbagai Pendekatan dalam Proses Belajar Mengajar. Jakarta: Bumi Aksara.

Ngodhe,S. O., Raburu, P.O., Arara, Orwa, P.O., \& Otieno, A. 2013. Spation Termporal Variations in Phytoplankton Community Structure in Small Water 
Bodies within Lake Victoria Basin, Kenya. African Journal of Environmental Science and Technology 7 (9): 862-873.

Pirza \& Andi, 2008.Hubungan Keragaman Fitopalankton dengan Kualitas Air di pulau Buluang, Kabupaten Taklar, Sulawesi Selatan.Jurnal Biodiversitas, 9 (3): 217-221.

Rahmani, Poorbagher, H. Javanshir, \& Kamangar, B. B. 2013. Effectss of Agriculture, Tourism and the Dam on Eutrophic Status of the Zerebar Lake, Iran Thasin.International Journal of Advanced Biological and Biomedical Research Volume 1(4) 403-420.

Rea, R.V,Dexter P. \& Hodder. 2007. Improving a Field School Curriculum Using Modularized Lessons and Authentic CaseBased Learning. Journal of Natural Resources and Life Sciences Education, (36): 1118.

Samsidar, Ma'ruf, K. \& Salwiya 2013. Struktur Komunitas dan Distribusi Fitoplankton di Rawa Aopa Kecamatan Angata Kabupaten Konawe Selatan.
Jurnal Mina Laut Indonesia, 2 (6): 109-119.

Setiawan, D. 2008. Struktur Komunitas Makrozoobenthos Sebagai Bioindikator Kualitas Lingkungan Perairan Hilir Sungai Musi, Tesis S-2.Institut Pertanian Bogor.

Sediadi, A. 1999. Ekologi Dinoflagellata. Oseana 24(4): 21-30.

(Online (www.oseanografi.lipi.go.id), diakses pada 12 juli 2015

Sugiyono. 2010. Statistik Untuk Penelitian. Bandung: Afabeta.

Suwono, H. 2011. Dasar-Dasar Limnologi. Surabaya: ITS press.

Wardhana, W. A, 2004.Dampak Pencemaran Lingkungan. Yogyakarta: Penebit Andi.

Wilhm, J.L. 1975 Biological Indicator of pollution.In Whitton, B. A. River Ecology.Blackwell Scientific Publication. Oxford

Zulfia, N \& Aisyah.2013. Status Trofik Perairan Rawa Peninng Ditinjau dari Kandungan Unsur hara ( NO3 dan PO4) Serta Klorofil-a. Jurnal Bawal, 5 (3): 189-199. 